\title{
Štruktúra a diverzita hniezdnej ornitocenózy podhorskej obce v Javorníkoch (severozápadné Slovensko)
}

\author{
Structure and diversity of a breeding bird assemblage of a foothills \\ village in the Javorniky Mts. (NW Slovakia)
}

\section{Martin KORŇAN ${ }^{1,2}$}

\author{
${ }^{1}$ Katedra aplikovanej zoológie a manažmentu zveri, Lesnícka fakulta, Technická univerzita vo Zvolene, T. G. \\ Masaryka 20,96001 Zvolen, Slovakia; e-mail: martin.kornan@gmail.com \\ ${ }^{2}$ Centrum pre ekologické štúdie, Ústredie 14, 01362 Vel'ké Rovné, Slovakia
}

\begin{abstract}
Studies of bird assemblage ecology of Slovak suburban sites are uncommon in the Slovak ornithological literature. The objective of this study is to describe basic community characteristics of breeding bird assemblage of a foothills village Vel'ké Rovné in the Javorniky Mts. and compare results with the exiting studies from Slovakia. Bird counts were conducted by fixed radius $(100 \mathrm{~m})$ point count method $(n=20$ points per season) twice during the breeding season in the period 2017-2021. In total, 53 species (three absenting in points) (range 30-38 per year in samples) were detected in the village during five-year study. There were six dominant species $(\geq 5 \%)$ : Fringilla coelebs (14.84\%), Sylvia atricapilla (12.08\%), Cyanistes caeruleus (7.80\%), Phoenicurus ochruros (6.86\%), Parus major (6.33\%) and Motacilla cinerea (5.45\%). The mean total assemblage density was estimated on 54.27 ind./10 ha $(\sigma=5.07, n=5)$ varying from 48.06 to 61.91 ind./10 ha per year. Significant differences in total bird abundance per points among years were not detected by Friedman test. Monte Carlo individual-based rarefaction detected significant differences among years in species richness and Shannon index in large subsample of individuals, no differences were detected in absolute theoretical species richness (Chao 1 estimator). Total assemblage density was comparable to some of previous studies, yet some differences were found in dominant species structure.
\end{abstract}

Key words: bird community, structure, species richness, diversity, point counts, rural settlement

\section{Úvod}

Urbanizácia životného prostredia má zásadný vplyv na zmeny pôvodných ornitocenóz $\mathrm{v}$ rôznych časových a priestorových škálach. V posledných dekádach sa ekológii ornitocenóz urbanizovaného prostredia venuje zvýšená pozornost' predovšetkým $\mathrm{v}$ súvislosti s ochranou diverzity a životného prostredia a udržatel’ným urbánnym plánovaním (Evans et al. 2009, Lepczyk \& Warren 2012). Evans et al. (2009) zhrnul výsledky výskumu urbánnych ornitocenóz do nasledovných bodov: (1) Lokálne faktory $(\sim 1 \mathrm{~km})$ sú dôležitejšie ako regionálne determinanty štruktúry, (2) Hniezdne aj zimné urbánne ornitocenózy vykazujú silné vzt'ahy medzi druhmi a plochou (species-area relationships). Mechanizmy, ktoré ich určujú v urbánnych biotopoch sa zdajú byt' podobné z iných území t.j. väčšie plochy urbánnych biotopov majú vyššiu diverzitu biotopov, redukovaný okrajový efekt a podporujú väčšie a stabilnejšie populácie. (3) Urbánne oblasti sú vel'mi dynamické systémy, kde sukcesné štádium vegetácie môže mat' zásadný vplyv na ich ornitocenózy. Niekol'ké štúdie uvádzajú, že nárast štruktúry a diverzity vegetácie, minimálne stromov a krov, môže zvyšovat’ druhovú 
bohatost' vtákov, ale podobné vzorce platia aj pre lesné ornitocenózy vo všeobecnosti (pozri Wiens 1989 a Fuller 2012) (4) Disturbancie návštevníkmi, dopravou a domácimi zvieratami môžu mat' negatívny vplyv na hustoty vtákov napriek tomu, že mnohé druhy sú adaptované na urbánne prostredie. (5) Početné štúdie vrátane experimentálnych zistili pozitívny vplyv prikrmovania vtákov l'ud'mi na hniezdnu úspešnost', pomery prežívania a vel'kosti populácí́ vo vidieckom prostredí, čo naznačuje, že doplnková strava môže ovplyvňovat' štruktúru a organizáciu urbánnych ornitocenóz. Umelé osvetlenie môže mat' zásadný vplyv na denné rytmy vtákov v urbánnom prostredí a tým aj ovplyvňovat' fenologické vzorce hniezdenia a organizácie ornitocenóz (Kempenaers et al. 2010, Dominoni et al. 2014). Druhovo-špecifická adaptabilita vtákov na urbánne prostredie je dôležitou charakteristikou pri modelovaní vývoja urbánnych vtáčích zoskupení (Callaghan et al. 2020). Urbánna avifauna má vo všeobecnosti väčšiu tendenciu $\mathrm{k}$ vyššej uniformite $\mathrm{v}$ geografickom priestore v Európe a tým vyššej biotickej homogenizácii ornitocenóz (Ferenc et al. 2014), čo je chápané ako degradácia pôvodnej diverzity.

Výskum vidieckych a mestských ornitocenóz začal na Slovensku ešte v 60-tych rokoch minulého storočia (napr. Feriancová-Masárová \& Brtek 1969; Salaj 1971, 1974; FeriancováMasárová \& Ferianc 1982; FeriancováMasárová 1994, 1997). Všetky slovenské práce boli deskriptívneho charakteru a hodnotili druhovú štruktúru, charakter výskytu a neskoršie aj kvantitatívne cenotické charakteristiky ornitocenóz ako početnosti, hustotu a dominanciu. Medzi najkvalitnejšie štúdie z hl'adiska použitej metodiky patria práce Urbanovej \& Kociana (1997) z Oravy (obce Oravský Podzámok a Huty) a Országhovej \& Jakubičkovej (1998) z obce Hruboňovo na západnom Slovensku, kde autori sledovali štruktúru hniezdnych ornitocenóz pomocou mapovacej metódy počas dvoch hniezdnych sezón. Časovo najdlhší výskum na Slovensku robila Feriancová-Masárová, ktorá sledovala prerušovane štruktúru ornitocenózy v 5 ha sčítacej ploche vo vilovej časti Bratislavy počas celého roka v obdobiach 1979 - 1992
(Feriancová-Masárová 1994), 1996 - 1999 (Feriancová-Masárová 2002) a 2000 - 2006 (Feriancová-Masárová 2007). FeriancováMasárová \& Ferianc (1985) zhodnotili kvantitatívnu štruktúru ornitocenózy 21 okresných miest západo- a stredoslovenských krajov v rokoch 1980 - 1984. Feriancová-Masárová (1997) publikovala aj porovnávaciu historickú štúdiu o štruktúre ornitocenóz urbánnych celkov južnej časti Malých Karpát v dvoch časových obdobiach 1963 - 65 a 1995 - 97. Štruktúru ornitocenóz a charakter výskytu druhov kopaničiarskeho osídlenia južného Podpol'ania a západného Slovenska spracovali Krištín \& Zach (1993) a Kalivodová (1997). Mnohé z týchto citovaných prác nemajú striktný dizajn (kvantitatívneho) výskumu vtáćích zoskupení, a preto sú výsledky týchto prác t’ažko porovnatel'né.

Vzhl'adom na to, že rigoróznych kvantitatívnych štúdií ornitocenóz vidieckeho osídlenia je na Slovensku doposial' pomerne málo, v predloženej práci predkladám výsledky výskumu bodovou metódou ornitocenózy obce z oblasti pohoria Javorníky. Ciele predloženej práce sú nasledovné: (1) popísat' štruktúru hniezdnej ornitocenózy počas obdobia piatich rokov (2017 -21) na základe základných cenotických parametrov ako abundancia, hustota a dominancia, (2) zhodnotit' druhovú bohatost' a diverzitu ornitocenózy v jednotlivých rokoch a štatisticky testovat' či sú v týchto metrikách medziročné rozdiely, (3) zhodnotit' a porovnat' výsledky so štúdiami ornitocenóz urbánnych a rurálnych biotopov z iných oblastí Slovenska.

\section{Materiál a metodika}

\section{Charakteristika skúmanej oblasti}

Výskum bol robený v katastri obce (intravilán aj extravilán) Vel'ké Rovné (49 $17^{\circ} 28^{\prime \prime} \mathrm{S}$, $\left.18^{\circ} 35^{\prime} 00^{\prime \prime} \mathrm{V}\right)$ pričom sčítací bodový transekt prechádzal popri hlavnej cestnej komunikácii z časti obce Ústredie až po čast' Ivor (obr. 1). Obec leží na severozápadnom Slovensku v pohorí Javorníky (370 - 910 m n. m. v chotári s rozlohou 4060 ha) v kotline rieky Rovňanky. V súčasnosti v obci žije 4068 obyvatel'ov vo 
vyše 900 rodinných domoch a 320 bytoch na sídlisku (www.velkerovne.sk). Čast' obyvatel'ov žije aj na lazoch, ktoré sa tiahnu po svahoch na oboch stranách toku Rovňanky. Nadmorská výška jednotlivých sčítacích bodov sa pohybovala od 386,7 do 499,7 m n. m. (príloha 1). Body transektu reprezentovali rôzne typy biotopov od intravilánu obce až po lesnatejšiu krajinu a odrážali charakter súčasného osídlenia a tým aj gradient lesnatosti (obr. 1 a 2). Mnohé body boli v blízkosti toku Rovňanka, čo sa odrazilo prítomnost'ou vodných druhov vo vzorkách. V okolí urbánnych celkov sa nachádzajú aj lúky, pasienky, polia a sady ovocných stromov (hlavne jablone, slivky, hrušky a čerešne), ktoré obhospodarujú predovšetkým miestny obyvatelia (obr. 2c, d). V lesoch v oblasti Vel'kého Rovného dominujú stromy Picea abies, Fagus sylvatica a Abies alba s prímesou d'alších drevín ako napr. Acer pseudoplatanus, Acer campestre, Acer platanoides, Larix decidua, Populus tremula, atd'. Dominantné sú smrekové monokultúry a hospodárske zmiešané lesy. Lesy v katastri obce sú intenzívne lesnícky obhospodarované a v mnohých oblastiach katastra, kde prebiehala t’ažba, sú vysadené mladiny. Príbrežné porasty okolo rieky Rovňanka majú charakter horského jelšového lužného lesa, kde dominujú Alnus incana a druhy rodu Salix s prímesou iných drevín.

Územie patrí z fytogeografického hl'adiska do oblasti holarktis, eurosibírskej podoblasti a stredoeurópskej provincie. Z hl'adiska fytogeograficko-vegetačného členenia kataster obce patrí do bukovej zóny a flyšovej oblasti. Zo zoogeografického hl'adiska územie patrí oblasti paleoarktu, eurosibírskej podoblasti, provincie listnatých lesov a podkarpatského úseku (Miklós et al. 2002).

\section{Kvantitatívny výskum vtákov}

Sčítanie vtákov bolo robené metódou bodového transektu (Bibby et al. 2000) v rokoch 2017 - 2021. Každý rok bol kvantitatívny vý-

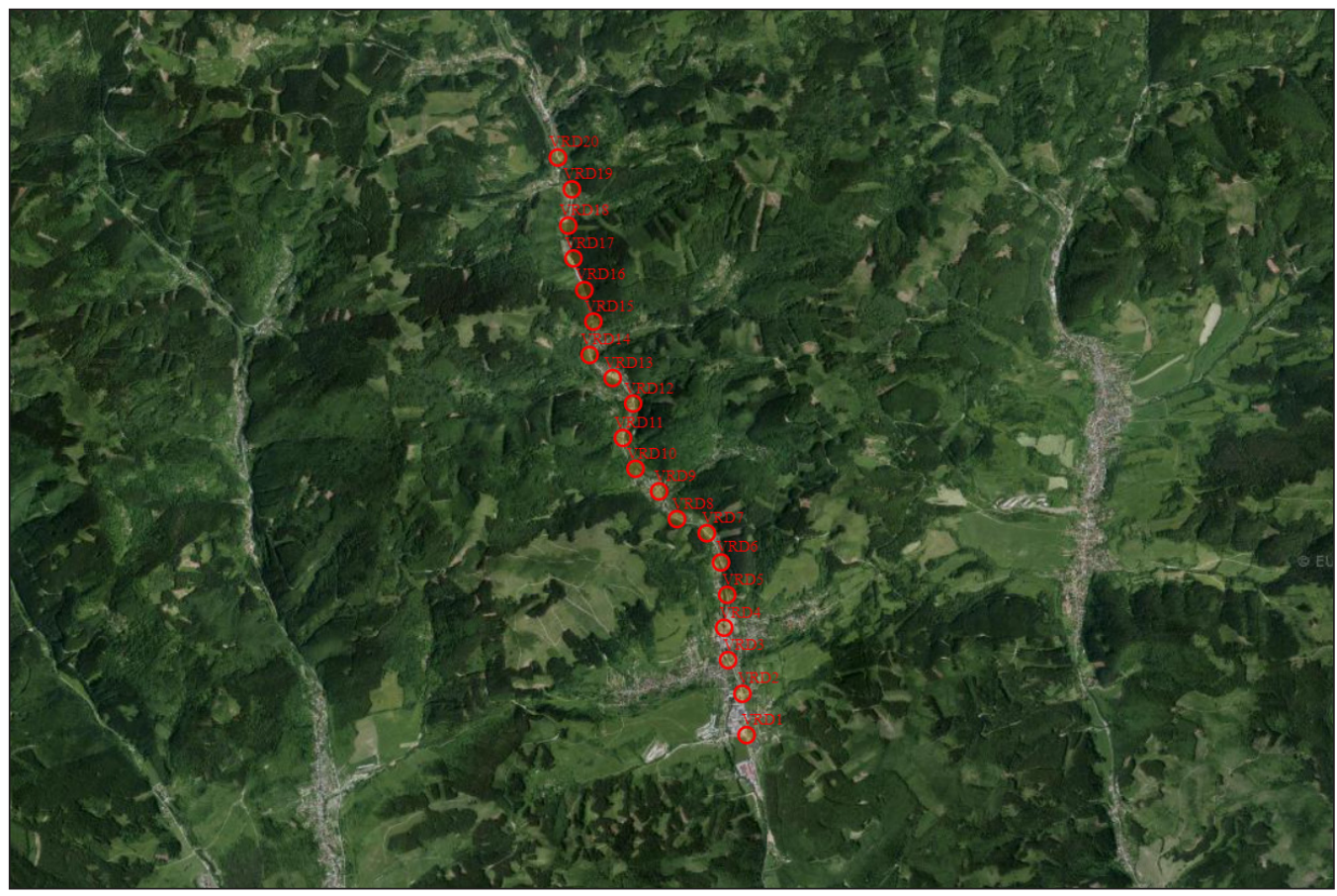

Obr. 1. Mapa bodového transektu popri hlavnej ceste 541 v katastri obce Velké Rovné. Prvý bod je $v$ časti obce Ústredie a posedný v časti Ivor. Zdroj: mapy.cz, letecké snímky.

Fig. 1. The map of point transect along the main road No. 541 in the cadastre of the village of Vel'ké Rovné. The first bird count point is in the part of village Ústredie and the last one in Ivor. Source: mapy.cz, aerial images. 

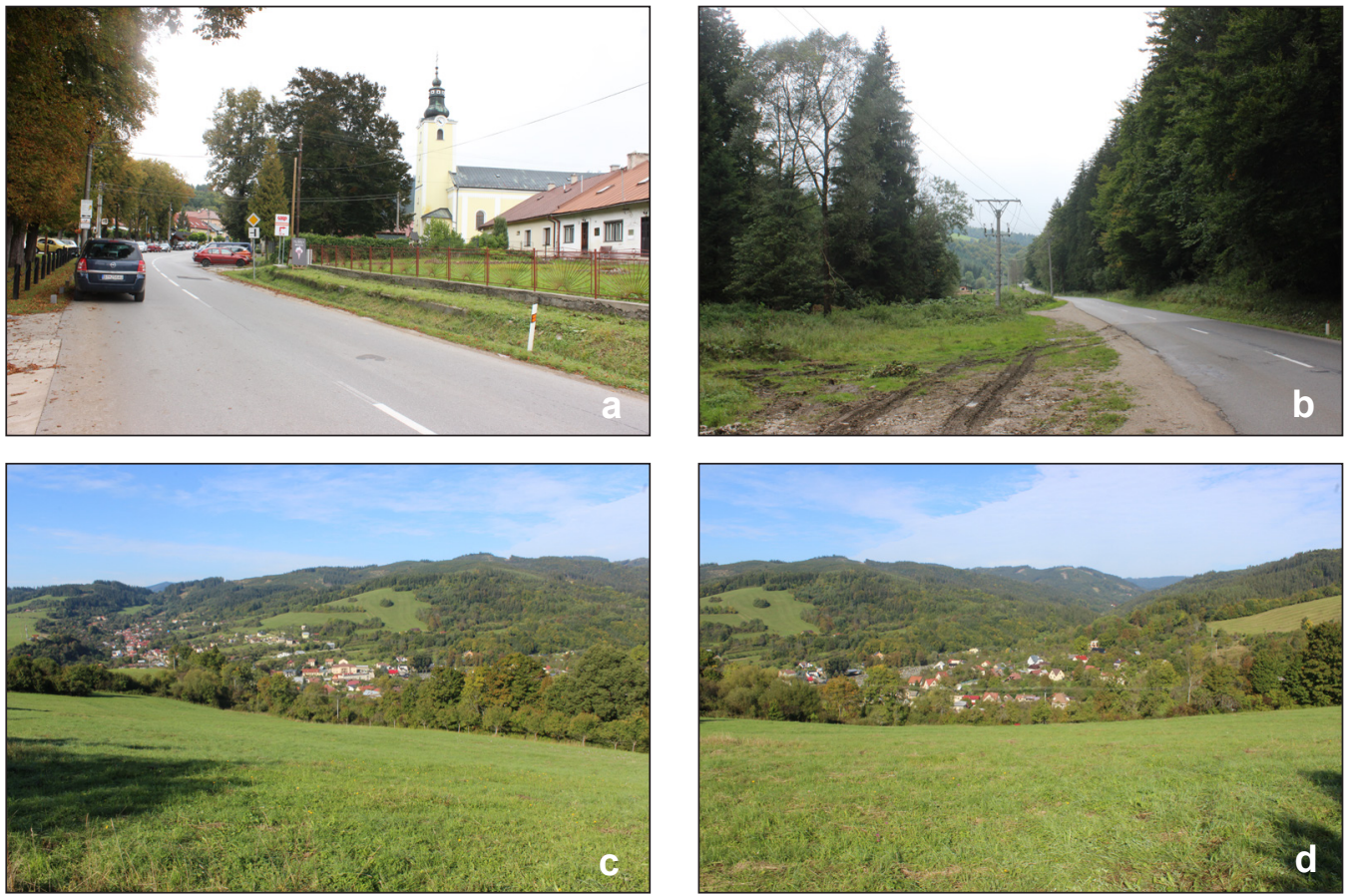

Obr. 2. Intravilán obce Vel'ké Rovné v oblasti sčítacieho bodu č. 3. Na l'avej časti obrázka vidno pagaštanový park, ktorý slúži na odpočinok občanov (a). V časti obce s miestnym názvom Mezdihájnice je motokrosová dráha. Oblast' je obklopená hospodárskymi lesmi (oblast' bodov č. 16 a 17) (b). Pohl'ad na intravilán centrálnej časti obce Vel'ké Rovné a okolitú krajinu pohoria Javorníky (c). Pohlad na údolie rieky Rovňanka a hrebene pohoria Javorníky s častou centrálnej časti obce. Na svahoch sú viditel'né kopaničiarke usadlosti (d) (foto autor).

Fig. 2. Intravillan of the village of Vel'ké Rovné in the area of the bird count point No. 3. On the left side of the picture, a horse chestnut park is visible that provides a leisure area for citizens (a). In the part of the village with the local name Mezdihájnice is a motocross areal situated. The area is surrounded by managed forests (area of points No. 16 and 17) (b). View on the intravilt lan of the central part of the vllage of Velké Rovné and surrounding landscape of the Javorniky Mts. (c). View on the valley of the river Rovňanka and the Javorniky Mts. ridges with a part of the central settlement of the municipality. On the slopes are visible hermitage settlements (d) (photo by author).

skum robený dva krát počas hniezdnej sezóny (prvé sčítanie: 27. máj - 4. jún, druhé sčítanie: 22. - 30. jún) a použitých bolo 20 bodov (plocha 62,8 ha). Minimálna vzdialenost' medzi bodmi bola $300 \mathrm{~m}$. Sčítanie sa realizovalo formou štandardizovaných formulárov formátu A4, kde boli vyznačené koncentrické kruhy vo vzdialenostných sektoroch 0 - 25, 25 - 50, 50 - 100 a $100+$ m. Počas štandardizovanej dížky sčítania 5 minút boli zaznamenávané všetky vizuálne a akusticky zistené vtáky podl'a systému symbolov, ktorý sa používa pri kvantitatívnom výskume predovšetkým u mapovacej metódy (Kropil 1992). Výskum sa robil len v ranných hodinách približne od 4:30 do 9:00 SEČ. Na stanovenie abundancií jednotlivých populácií sa použili údaje z bodov s polomerom $100 \mathrm{~m}$.
Spievajúce samce a aktívne hniezdo sa počítali ako jeden pár t. j. dve indivíduá. Jedince druhov Apus apus, Delichon urbicum a Hirundo rustica, ktoré prelietavali nad sčítacími bodmi, neboli zahrnuté do výpočtov cenotických charakteristík a metrík diverzity. Sčítacie body boli zamerané pomocou GPS prístrojov (Garmin GPSmap 64s, Garmin GPSmap 66i). Geografické súradnice (WGS84) a nadmorské výšky jednotlivých bodov sú uvedené v prílohe 1 .

\section{Analýza údajov}

$\mathrm{Na}$ analýzu štruktúry ornitocenózy boli použité základné cenotické charakteristiky: početnost' (abundancia), hustota (denzita) a dominancia, ktoré boli počítané v prostredí MS Excel. Abundancia bola počítaná ako suma maximál- 
nych početností jedincov z dvoch sčítaní vo všetkých bodoch $\mathrm{v}$ jednotlivých rokoch. Hustota bola vyjadrená ako počet jedincov na štandardizovanú plochu 10 ha, pričom na výpočet boli použité sumárne abundancie populácií zo všetkých bodov. Dominancia (\%) bola počítaná ako percentuálny podiel abundancií populácií jednotlivých druhov z celkovej abundancie ornitocenózy.

Na hodnotenie diverzity ornitocenózy boli použité metriky druhovej bohatosti (počet druhov), Chao 1 estimátor druhovej bohatosti a Shannonov index diverzity (prirodzený logaritmus, ln). Chao 1 estimátor sa používa na odhad absolútnej t.j. maximálnej druhovej bohatosti vo vzorkách z údajov abundancií (Gotelli $\&$ Colwell 2011). Do všetkých metrík diverzity boli zahrnuté aj sp/p. (species singularis a pluralis - neurčený druh alebo druhy jedného rodu) druhy. Na štatistické testovanie rozdielov medzi jednotlivými rokmi som použil Monte Carlo zried'ovanie na štandardizovaný počet jedincov (Monte Carlo individual-based rarefaction) (Gotelli \& Colwell 2011). Metriky diverzity medzi rokmi sa porovnávali na štandardizované podvzorky 50, 100 a 300 indivíduí, pričom sa testoval prekryv $95 \%$ intervalov spol'ahlivosti simulácií hodnôt metrík diverzity. Horná hranica početnosti pre vzácne druhy bola stanovená na 5. Pri výpočtoch sa použilo 10000 iterácií a randomizačný algoritmus bez opakovania. Hladina významnosti vo všetkých Monte Carlo testoch bola 0,05 . Všetky simulácie boli robené v programe EstimateS 9.1.0. (Colwell 2013).

Medziročné rozdiely v abundancii a druhovej bohatosti vzoriek boli testované pomocou neparametrického Friedmanovho testu na zhodnost' mediánov. Hladina významnosti všetkých testov bola 0,05 . Výpočty boli robené v prostredí programu Past 4.06b (Hammer 2021).

\section{Výsledky}

\section{Celková druhová bohatost'}

V sledovanom období 2017-2021 bolo na všetkých bodoch zistených celkovo 47 druhov vtákov $(3 \times$ druh sp/p. som nepočítal) a ak k tomu pripočítame aj tri druhy preletujúce ponad body - Apus apus, Delichon urbicum a Hirundo rustica, ktoré určite v obci hniezdili - tak celkový počet druhov bol 50. Okrem týchto druhov boli ešte zistené ako hniezdiče Streptopelia decaocto, Picus viridis a Pica pica, ktorí neboli zachytený počas sčítaní. V minulosti som mal bežne zaznamenané aj hniezdenie Linaria cannabina. Počet druhov v jednotlivých rokoch vo vzorkách varíroval od 27 (2020) do 35 (2017) bez spomínaných troch preletujúcich a troch $\mathrm{sp} / \mathrm{p}$. druhov, pričom priemerný počet druhov bol $31(\sigma=3,39 ; n=5)$. Za rádiusom sčítacích bodov $100 \mathrm{~m}$ mimo intravilánu obce boli zistené (počuté) d'alšie druhy ako napr. Ficedula parva, Phylloscopus trochilus, Phylloscopus sibilatrix ai., ale jednalo sa už predovšetkým o lesné druhy.

\section{Abundancia, dominancia a hustota}

$\mathrm{Na}$ základe priemerných hodnôt abundancie možno šest' druhov pokladat' za dominantné ( $\geq 5 \%$ ): Fringilla coelebs $(14,84 \%)$, Sylvia atricapilla (12,08\%), Cyanistes caeruleus (7,80\%), Phoenicurus ochruros (6,86\%), Parus major (6,33\%) a Motacilla cinerea $(5,45 \%)$ (tab. 1). Priemerná hustota týchto druhov sa pohybovala $v$ rozmedzí 2,96 - 8,05 ind./10 ha.

Celková priemerná hustota ornitocenózy bola 54,27 ind./ 10 ha $(\sigma=5,07 ; n=5)$ bez troch preletujúcich druhov (tab. 1), ktoré spomínam v časti Celková druhová bohatost'. Celková hustota ornitocenózy $\mathrm{v}$ jednotlivých rokoch varírovala od 48,06 (2020) do 61,91 ind./10 ha (2017). Medziročné rozdiely v celkovej abundancii ornitocenózy bodových vzoriek $(n=20)$ medzi jednotlivými rokmi neboli signifikantne rozdielne podla výsledku Friedmanovho testu $\left(\chi^{2}\right.$ korigované pre rovnaké hodnoty $=7,82$; $\mathrm{df}=4 ; \mathrm{P}=0,099)$.

\section{Druhová bohatost' a diverzita}

Priemerné hodnoty druhovej bohatosti štandardizovanej Monte Carlo zried'ovaním na 300 jedincov sa pohybovali v intervale 28,98 - 36,19 druhov (tab. 2). Na základe výsledkov Monte Carlo testov zried'ovaním nebola druhová 


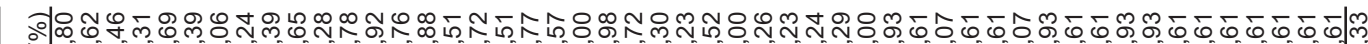
ว

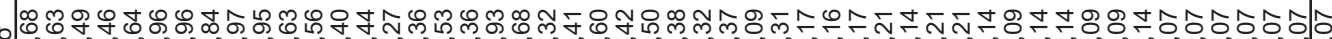

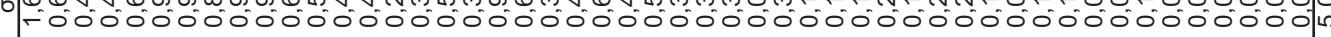

ฌం

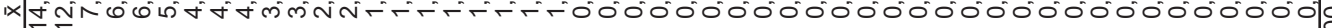

ส

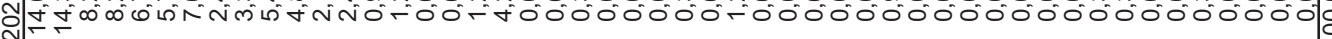

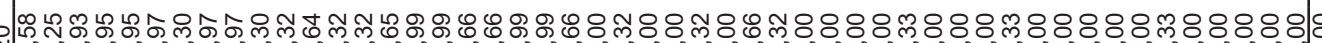
¿

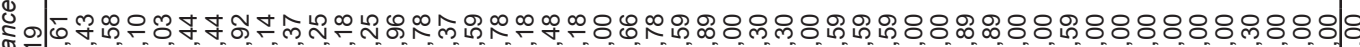

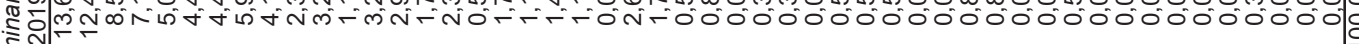
हิ

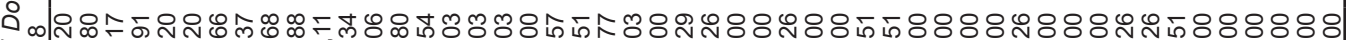

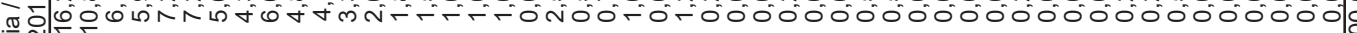

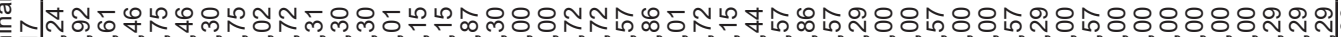
हैํํำ

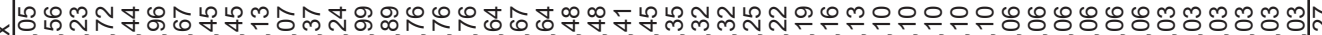
oo

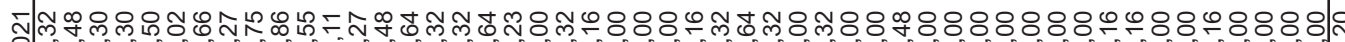

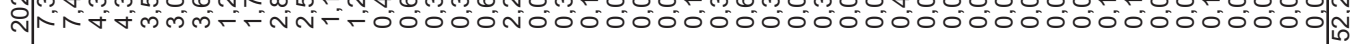

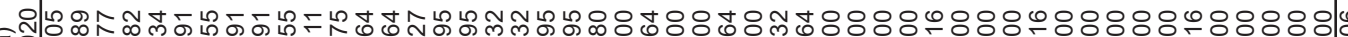
व

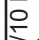

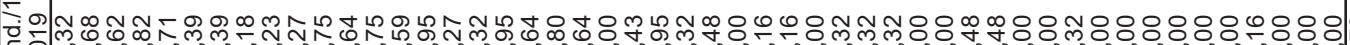

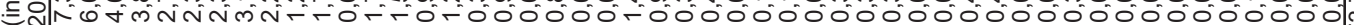
空

Tొ

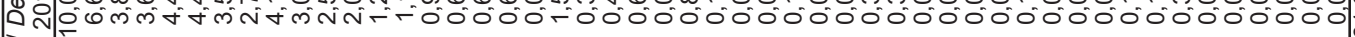

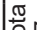
흔ำน

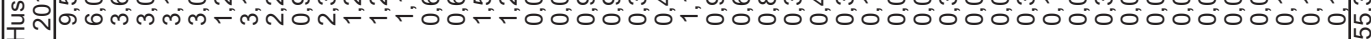

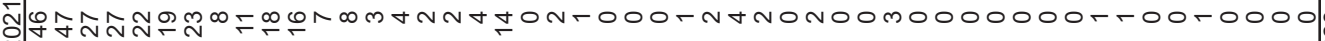

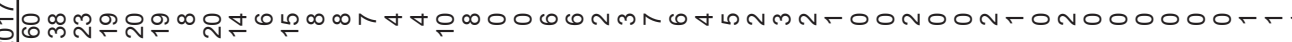

שุ

ND

$\sin 5$

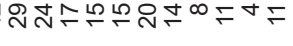


4 Tab. 1. Početnost' (abundancia), hustota (ind./10 ha), dominancia (\%) a smerodajná odchýlka a variačný koeficient hustoty jednotlivých populácií vtákov v hniezdnej ornitocenóze intravilánu a extravilánu obce Vel'ké Rovné v rokoch 2017 - 2021. Dominantné druhy sú vyznačené hrubým písmom.

4 Table 1. Abundance, density (ind./10 ha), dominance (\%) and standard deviation and coefficient of variation of the density of individual bird populations within a breeding bird assemblage of the intravillan and extravillan of the village of Velké Rovné in the years 2017-2021. Dominant species are in bold.

- Tab. 2. Porovnanie druhovej diverzity v jednotlivých rokoch metódou zried'ovania na štandardizovaný počet jedincov na základe výpočtu druhovej bohatosti, Chao 1 estimátora druhovej bohatosti a Shannovho indexu druhovej diverzity. Priemery a intervaly spolahlivosti (95\% IS) boli počítané na základe 10000 Monte Carlo simulácií randomizačným algoritmom bez opakovania.

- Table 2. Comparison of diversity metrices of species richness, Chao 1 estimator of species richness and Shannon index in individual years by the Monte Carlo individual-based rarefaction approach. Means and confidence intervals (95\% Cl) were computed on the basis of 10,000 Monte Carlo simulations with the randomization algorithm without replacement.

bohatost' rozdielna medzi jednotlivými rokmi na podvzorkách 50 a 100 jedincov (tab. 2). Rozdiely som zistil až na podvzorke 300 jedincov. Rok 2017 mal signifikantne vyššiu druhovú bohatost' ako roky 2018, 2020 a 2021 a ešte rok 2019 bol druhovo bohatší ako rok 2020. Párové porovnania medzi ostatnými rokmi neboli signifikantne rozdielne.

Priemerné hodnoty druhovej bohatosti podl'a Chao 1 estimátora na štandardizovaný počet 300 jedincov v období 2017 - 2021 boli v intervale hodnôt 29,78 - 38,96 druhov (tab. 2). Porovnaním intervalov spol'ahlivosti hodnôt druhovej bohatosti Chao 1 estimátora (metrika odhadu minimálnej asymptotickej druhovej bohatosti) na základe Monte Carlo simulácií som nezistil na žiadnej podvzorke signifikantné rozdiely medzi rokmi.

Priemerné hodnoty Shannonovho indexu v období 2017 - 2021 na základe Monte Carlo simulácií zried'ovaním boli na podvzorke 300 jedincov 2,83 až 3,07 natov (tab. 2). Na základe výsledkov Monte Carlo testov zried'ovaním neboli hodnoty Shannonovho indexu rozdielne medzi jednotlivými rokmi na podvzorkách 50 a 100 jedincov (tab. 2). Rozdiely som zaznamenal až na podvzorke 300 jedincov. Rok 2017 mal signifikantne vyššiu druhovú diverzitu ako roky 2018, 2020 a 2021. Rok 2018 mal signifikantne nižšiu hodnotu Shannonovho indexu ako roky 2019 a 2020. Rok 2019 vyššiu ako roky 2020

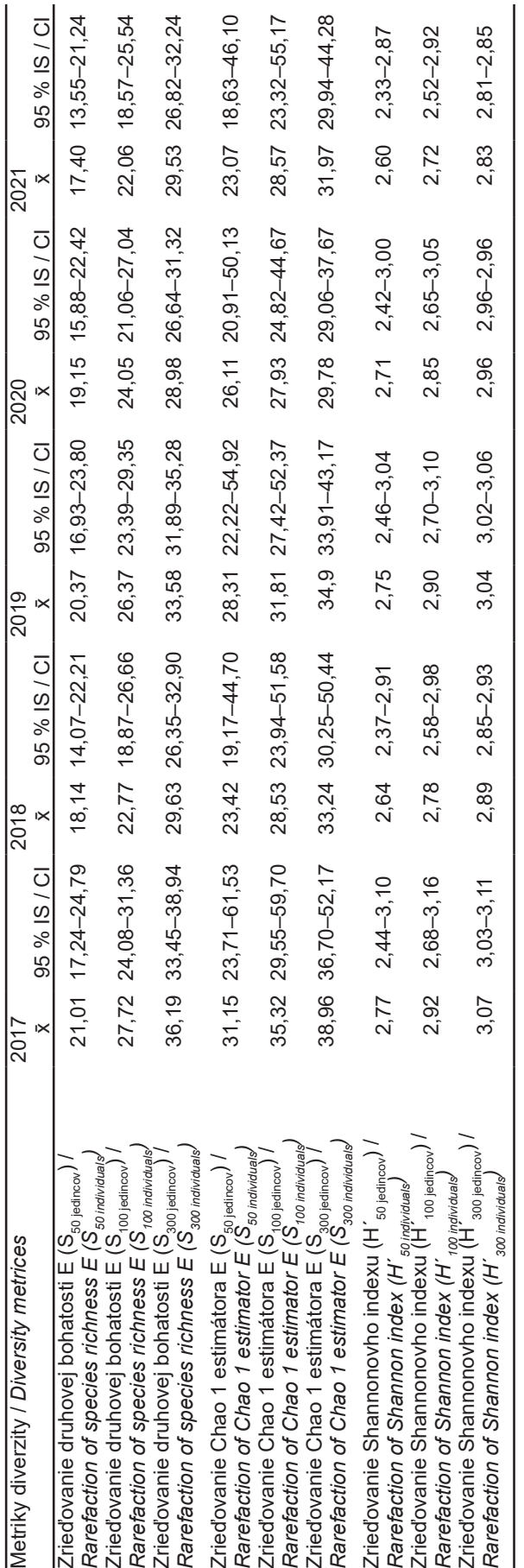


a 2021. Signifikantne vyššiu druhovú diverzitu mal aj rok $2020 \mathrm{v}$ porovnaní s rokom 2021.

Medziročné rozdiely v celkovej druhovej bohatosti ornitocenózy bodových vzoriek $(n=20)$ medzi jednotlivými rokmi neboli signifikantne rozdielne podl'a výsledku Friedmanovho testu $\left(\chi^{2}\right.$ korigované pre rovnaké hodnoty $=8,47$; $\mathrm{df}=4 ; \mathrm{P}=0,077)$.

\section{Diskusia}

Na základe výsledkov práce možno konštatovat' nasledovné závery:

- Druhová bohatost' a diverzita (Shannonov index) neboli stabilné medzi rokmi, lebo viacero párových medziročných porovnaní bolo rozdielnych na základe testu pomocou Monte Carlo zried'ovania. Friedmanov test medziročné rozdiely medzi mediánmi druhovej bohatosti bodov nepreukázal, preto z dôvodu nejednoznačnosti testov nemožno konštatovat' jednoznačný záver, ale pri zvážení bodu dva možno skôr zamietnut' rozdielnost' druhovej bohatosti medzi rokmi.

- Celková teoretická druhová bohatost' odhadovaná na základe Chao 1 estimátora bola stabilná a medzi rokmi som nezistil žiadne rozdiely.

- Signifikantné rozdiely v celkovej abundancii ornitocenózy na základe testovania mediánov z 20-tich bodových vzoriek Friedmanovým testom neboli zistené, čo naznačuje stabilitu celkovej abundancie.

\section{Druhová štruktúra a dominancia}

$\mathrm{V}$ tejto kapitole sa pokúsim porovnat' a zhodnotit’ štruktúru ornitocenózy obce Vel'ké Rovné s podobnými prácami zo Slovenska, pričom si uvedomujem, že porovnávané údaje boli robené rôznymi metodikami v rôznych časových a priestorových rámcoch a prostrediach, preto je potrebná náležitá opatrnost'. Centrum obce Oravský Podzámok (mapovacia plocha $11 \mathrm{ha}$ ) a jej čast' Stodolisko (mapovacia plocha 12,9 ha) so zástavbou rodinných domov so záhradami a obec Huty (mapovacia plocha 26 ha) s typickým oravským kopaničiarskym osídlením sledovali Urbanová \& Kocian (1997) počas hniezdneho a mimohniezdneho obdobia od apríla 1995 až po január 1997. Výskum bol robený mapovacou metódou, pričom autori použili 8 - 12 snímok v jednotlivých plochách počas hniezdnej sezóny od apríla až po koniec júla. Maximálna celková priemerná hustota ornitocenózy bola zistená v lokalite centrum $80,3 \mathrm{p} / 10$ ha, nasledovala lokalita Stodolisko so 44,6 p/10 ha a najnižšia bola v obci Huty 26,8 p/10 ha. Priemerná celková hustota ornitocenózy Vel'kého Rovného bola 54,3 ind./10 ha t.j. vel'mi blízka lokalite Huty s lazníckym osídlením. V lokalite Oravský Podzámok centrum zaznamenali celkovo osem dominantných druhov (Delichon urbicum (15,8 \%) a Passer domesticus (12,9\%), Fringilla coelebs (9,9\%), Phoenicurus ochruros (8,2\%), Motacilla alba (7,9\%), Chloris chloris (7,6\%), Serinus serinus (7,6 \%) a Sturnus vulgaris $(5,8 \%)$ ), v lokalite Stodolisko bolo 6 dominantov (Passer domesticus (39,1\%), Delichon urbicum (9,3\%), Phoenicurus ochruros (8,5\%), Fringilla coelebs $(6,8 \%)$, Chloris chloris $(6,0 \%)$ a Serinus serinus $(5,1 \%)$ ) a v ploche obce Huty bolo tiež šest' dominantných druhov (Phoenicurus ochruros $(15,6 \%)$ a Delichon urbicum (10,9\%), Serinus serinus $(9,9 \%)$, Fringilla coelebs $(9,2 \%)$, Motacilla alba (7,8 \%) a Hirundo rustica $(5,4 \%))$. V obci Vel'ké Rovné bolo podl'a priemerných hodnôt abundancie zistených celkovo šest' dominantných druhov, ale zhodné boli len Fringilla coelebs a Phoenicurus ochruros. Na Orave bol Delichon urbicum na každej ploche v poradí dominancie prvý alebo druhý druh. V kruhových plochách počas sčítania som abundanciu tohto druhu nezaznamenával, lebo sa jednalo predovšetkým o preletujúce jedince. Výsledky bodových sčítaní sú skreslené, lebo hniezda neboli vyhl'adávané v sčítacích bodoch.

Országhová \& Jakubičková (1998) sledovali ornitocenózy štyroch biotopov v katastri obce Hruboňovo v Nitrianskej pahorkatine pomocou mapovacej metódy v rokoch 1997 a 1998, pričom ornitocenózy boli snímkované $8-12$ krát počas hniezdnej sezóny v každej lokalite. Časti obce Sul'any (plocha 57 ha) a Výčapky (plocha 60 ha) možno pritom charakterizovat' ako vidiecke urbánne biotopy. Vzhl'adom na to, 
že v článku neboli uvádzané priemerné hodnoty základných cenotických charakteristík, tieto hodnoty som dopočítal pre porovnanie s mojimi výsledkami. V lokalite Sul'any bolo zistených pät' dominantných druhov na základe hodnôt priemernej abundancie (Delichon urbicum (20,9\%), Columba livia f. domestica (20,3\%), Passer domesticus (16,7 \%), Streptopelia decaocto $(6,8 \%)$ a Hirundo rustica $(5,4 \%))$, pričom dominantné druhy boli podobné s ornitocenózou z časti Výčapky, kde boli zistené štyri dominantné druhy (Passer domesticus (33,2\%), Hirundo rustica (8,5\%), Streptopelia decaocto $(7,6 \%)$ a Phoenicurus ochruros $(5,4 \%)$ ). Ornitocenóza obce Vel'ké Rovné a časti obce Hruboňovo Sul'any nemali žiadny spoločný dominantný druh. Phoenicurus ochruros bol spoločný dominantný druh v porovnaní s ornitocenózou časti Výčapky. Priemerná celková hustota ornitocenózy v lokalite Sul'any bola $30,1 \mathrm{p} / 10$ ha $(24,9-35,3)$ a $17,5 \mathrm{p} / 10$ ha $(13,2$ -21,8) v časti obce Výčapky. Hodnoty celkovej denzity ornitocenózy obce Vel'ké Rovné boli podobné časti Sul'any Hruboňova $(48,1$ - 61,9 ind./10 ha).

Feriancová-Masárová \& Ferianc (1985) uvádzajú celkovú hustotu ornitocenóz 21 okresných miest v rozmedzí 116,5 - 652,0 ind./10 ha, pričom najviac slovenských miest patrilo do kategórie 250,1 - 300 ind./10 ha, čo sú výrazne vyššie hodnoty ako som zistil počas piatich rokov vo Vel'kom Rovnom. Zo Žiliny uvádzajú celkovú hustotu 251 ind./10 ha. Podstatne vyššie populačné hustoty zistili u druhov Streptopelia decaocto, Passer domesticus a Sturnus vulgaris zo Žiliny. V práci nie je popísaná metodika kvantitatívneho výskumu, preto si netrúfam rozdiely v záveroch komentovat'.

Vzhl'adom na nerigorózny charakter metodického dizajnu a celkovú rozdielnost' zberu údajov ostatných štúdií ornitocenóz, ktoré uvádzam v Úvode, neporovnávam výsledky, nakol'ko by to mohlo viest' $\mathrm{k}$ zavádzajúcim interpretáciám. Týka sa to aj d’alšej podkapitoly druhová bohatost'.

\section{Druhová bohatost'}

Na ploche v centre obce Oravský Podzámok sa zistilo 25 hniezdičov, na ploche v lokalite Stodolisko 22 hniezdičov a na ploche v obci Huty 21 hniezdičov počas dvoch hniezdnych sezón (Urbanová \& Kocian 1997). Celková druhová bohatost' týchto výskumných plôch je nižšia v porovnaní s 53 druhmi zistenými v obci Vel'ké Rovné. Môže to byt' predovšetkým dôsledkom troch faktorov a to väčšej vel'kosti vzorky 62,8 ha (plocha 20 bodov), dlhšieho obdobia výskumu (2 vs. 5 rokov) a vyššou heterogenitou prostredia v bodových vzorkách. Jednotlivé oravské plochy mali do istej miery druhovo-špecifickú štruktúru ornitocenózy, ale dvojročný výskum bol pomerne krátky na stanovenie presnejšej skladby druhov. Lokality centrum a Stodolisko Oravského Podzámku sa líšili 9 druhmi, lokalita centrum a obec Huty 16 druhmi a lokality Stodolisko a Huty 11 druhmi.

Országhová \& Jakubičková (1998) zistili celkovo 27 (rozpätie 22 - 24) a 26 (rozpätie 20 - 22) druhov v ornitocenózach častí obce Sul'any a Výčapky Hruboňova počas dvoch rokov výskumu. Tieto hodnoty sú podstatne nižšie ako druhová bohatost' ornitocenózy obce Vel'ké Rovné, čo môže prioritne súvisiet's podobnými faktormi ako som uvádzal predchádzajúcom odstavci. Na rigorózne porovnanie metrík diverzity z oboch výskumov by bolo potrebné údaje testovat' pomocou Monte Carlo zried'ovania na štandardizovaný počet jedincov. Z takýchto testov by bolo možné objektívne hodnotit' rozdiely v metrikách diverzity.

Z ostatných faunistických prác spomeniem štúdiu Feriancovej-Masárovej \& Ferianca (1982) o vtákoch Bratislavy, v ktorej uvádzajú celkovo 198 druhov v teritóriu tohto mesta, pričom maximálnu druhovú bohatost' uvádzajú z vilovej štvrti, celkovo 98 druhov, z čoho $34 \%$ boli nidifikanty. Ostatné urbánne biotopy podl'a ich klasifikácie (staré mesto, sídliská, dediny a predmestia) mali výrazne zníženú druhovú bohatost' - 33, 39 a 40 druhov. V neskoršej faunistickej práci Feriancová-Masárová \& Kalivodová (2005) uvádzajú 229 druhov z Bratislavy v období 1991-2003, pričom cel- 
kový zistený počet druhov odhadujú na 258. Feriancová-Masárová \& Ferianc (1985) zistili druhovú bohatost' 14 - 33 hniezdiacich druhov v 21 okresných mestách v rokoch 1980-84, pričom najviac miest patrilo do kategórie 26-30 hniezdičov. Priemerná druhová bohatost' bola 23 nidifikantov. V Žiline, ktorá bola vtedy okresným mestom, kde patrila aj obec Vel'ké Rovné (vzájomná vzdialenost' približne $23 \mathrm{~km}$ ) autori uvádzajú podstatne nižšiu druhovú bohatost' - 31 hniezdičov. Objektívne vysvetlit’ tento vel'ký rozdiel v druhovej bohatosti hniezdičov, okolo 20 druhov, medzi Vel'kým Rovným a Žilinou si netrúfam, nakol'ko len z hl'adiska priestorovej vel'kosti oboch urbánnych celkov je to opačné ako by sme mali očakávat'.

Záverom by som chcem poukázat' na pomerne málo kvalitných kvantitatívnych štúdií vtáčích zoskupení urbánnych biotopov z územia Slovenska, ktoré by boli schopné poskytnút' objektívne informácie o druhovej skladbe, metrikách diverzity a populačných hustotách druhov a vývoja týchto parametrov v časových škálach vo vzt’ahu k rámcom habitatových a krajinných parametrov na rôznych priestorých škálach. Niektoré štúdie boli robené študentami biológie, preto ich treba hodnotit's istou dávkou opatrnosti ako ich prvé vedecké publikácie. Do budúcnosti by som chcel vyzvat' všetkých slovenských ornitológov, aby aj urbánnym celkom venovali potrebnú pozornost', lebo urbanizácia krajiny je jeden z najvážnejších negatívnych faktorov poklesu pôvodnej biologickej diverzity v globálnom ponímaní (Primack et al. 2011).

\section{Literatúra}

Bibby C., Burgess N., Hill D. \& Mustoe S. 2000: Bird census techniques. - Academic Press, London.

Callaghan C. T., Major R. E., Cornwell W. K., Poore A. G. B., Wilshire J. H. \& Lyons M. B. 2020: A continental measure of urbanness predicts avian response to local urbanization. - Ecography 43: 528-538.

Colwell R. K. 2013: EstimateS: Statistical estimation of species richness and shared species from samples. Version 9. Persistent URL < purl.oclc.org/estimates>. Dominoni D. M., Carmona-Wagner E. O., Hofmann M., Kranstauber B. \& Partecke J. 2014: Individual- -based measurements of light intensity provide new insight into the effects of artificial light at night on daily rhythms of urban-dwelling songbirds. - Journal of Animal Ecology 83: 681-692.

Evans K. L., Newson S. E. \& Gaston K. J. 2009: Habitat influences on urban avian assemblages. - Ibis 151: $19-39$.

Ferenc M., Sedláček O., Fuchs R., Dinetti M., FraisSINET M. \& Storch D. 2014: Are cities different? Patterns of species richness and beta diversity of urban bird communities and regional species assemblages in Europe. - Global Ecology and Biogeography 23: 479-489.

FeriancovÁ-Masárová Z. 1994: Dynamics of ornithocoenosis in a residential district in Bratislava during 1979-1992. — Biológia 49: 263-269.

FERIANCOVÁ-Masárová Z. 1997: Hniezdne ornitocenózy urbánnych celkov južnej časti Malých Karpát v rokoch 1963-1965 a 1995-1997. — Tichodroma 10: 78-84.

FeriancovÁ-MasÁrová Z. 2002: Changes in ornithocoenosis of the nesting birds in a residential district of Bratislava. - Acta Zoologica Universitatis Comenianae 44: 103-106.

FERIANCOVÁ-MasÁRovÁ Z. 2007: Kvalita a kvantita ornitocenóz vilovej štvrte Bratislavy v rokoch 2000-2006. — Tichodroma 19: 59-68.

Feriancová-Masárová Z. \& BrTeK V. 1969: Vtáctvo južnej časti Malých Karpát. — Questiones Geobiologicae 6: 7-76, 105-134.

Feriancová-Masárová Z. \& Ferianc O. 1982: Vtáčie spoločenstvá Bratislavy. — Biológia 37: 609-623.

Feriancová-Masárová Z. \& Ferianc O. 1985: Štruktúra hniezdnych ornitocenóz západo- a stredoslovenských urbánnych celkov. - Biológia, Bratislava 40: 1031-1039.

Feriancová-Masárová Z. \& Kalivodová E. 2005: Bratislava. - Pp.: 55-79. In: Kelcey J.G. \& Rheinwald G. (eds.): Birds in European cities. Ginster-Verlag, St. Katharinen.

FUller R. J. (ed.) 2012: Birds and habitat: relationships in changing landscapes. - Cambridge University Press, Cambridge.

Gotelli N. J. \& Colwell R. K. 2011: Estimating species richness. - Pp.: 39-54. In: Magurran A. E, McGill B. J. (eds.): Biological diversity. Frontiers in Measurement and Assessment. Oxford University Press, Oxford.

Hammer Ø. 2021: PAST. Paleontological statistics. Version 
4.06. Reference manual. — Natural History Museum, University of Oslo, Oslo.

KALIVodovÁ E. 1997: Vtáky kopaničiarskeho osídlenia západného Slovenska. — Tichodroma 10: 97-102.

Kempenaers B., Borgström P., Loës P., Schlicht E. \& VAlCU M. 2010: Artificial night lighting affects dawn song, extra-pair siring success, and lay date in songbirds. - Current Biology 20: 1735-1739.

KrišTín A. \& ZACH P. 1993: Ornitocenózy južného Podpol’ania navrhovaného významného vtáčieho územia Európy. - Pp.: 106-116. In: Urban P. (ed.): Fauna Pol’any. Správa CHKO - Biosférickej rezervácie Polana, Lesnícka fakulta Technickej Univerzity a Ústav ekológie lesa SAV vo Zvolene, Zvolen.

KROPIL R. 1992: Odporúčané skratky a symboly pre terénne záznamy pri kvantitatívnych výskumoch vtákov. — Tichodroma 4: 21-34.

LEPCZYK C.A. \& WARREN P.S. (EDS.) 2012: Urban bird ecology and conservation. - Studies in Avian Biology 45, University of California Press, Berkeley.
Miklós L. ET AL. 2002: Atlas krajiny Slovenskej republiky. - Ministerstvo životného prostredia SR a Slovenská agentúra životného prostredia, Bratislava a Banská Bystrica.

OrszáGHOVÁ Z. \& JAKUBIČKOVÁ M. 1998: Vtáky Hruboňova (západné Slovensko). — Tichodroma 11: 99-111.

Primack R. B., Kindlman P. \& Jersáková J. 2011: Úvod do biologie ochrany př́rody. — Portál, Praha.

SALAJ J. 1971: Ornitocenóza obcí a l'udských obydlí Poiplia._-Acta Facultatis Pedagogicae, Banská Bystrica, Séria prírodovedná 3, Biológia a geológia: 65-81.

SALAJ J. 1974: Ekologické rozšírenie vtákov v južnej časti Krupinskej vrchoviny. - SPN, Bratislava.

UrbanOVÁ S. \& Kocian L'. 1997: Vtáčie spoločenstvá troch typov vidieckeho osídlenia na Slovensku. Tichodroma 10: 110-126.

WiEns J. A. 1989: The ecology of bird communities. Vol. 1: Foundations and patterns. — Cambridge University Press, Cambridge.

Došlo: 17. 8. 2021

Prijaté: 4. 10. 2021

Online: 30. 10. 2021

Príloha 1. Základné charakteristiky jednotlivých sčítacích bodov v obci Vel'ké Rovné v rokoch 2017 - 2021.

Appendix 1. Basic characteristics of individual bird count points in the village of Velké Rovné in the years 2017-2021.

\begin{tabular}{|c|c|c|c|}
\hline Č. / No. & Zemepisná šírka / Latitude & Zemepisná dížka / Longitude & $\begin{array}{l}\text { Nadmorská výška (m n.m.) / } \\
\text { Elevation ( } m \text { a.s.l.) }\end{array}$ \\
\hline 1. & 49,284604 & 18,586185 & 386,7 \\
\hline 2. & 49,288072 & 18,585641 & 387,2 \\
\hline 3. & 49,29088 & 18,583797 & 386,0 \\
\hline 4. & 49,293602 & 18,583302 & 388,8 \\
\hline 5. & 49,296352 & 18,583683 & 401,3 \\
\hline 6. & 49,299064 & 18,582898 & 402,0 \\
\hline 7. & 49,301521 & 18,581072 & 405,5 \\
\hline 8. & 49,302694 & 18,577231 & 411,2 \\
\hline 9. & 49,305014 & 18,574933 & 420,6 \\
\hline 10. & 49,30692 & 18,571898 & 425,7 \\
\hline 11. & 49,309498 & 18,57028 & 428,8 \\
\hline 12. & 49,312387 & 18,571602 & 440,2 \\
\hline 13. & 49,314517 & 18,568968 & 450,6 \\
\hline 14. & 49,316455 & 18,565993 & 458,4 \\
\hline 15. & 49,319251 & 18,566486 & 464,5 \\
\hline 16. & 49,321883 & 18,565312 & 471,5 \\
\hline 17. & 49,324541 & 18,56391 & 487,7 \\
\hline 18. & 49,327278 & 18,563254 & 489,4 \\
\hline 19. & 49,330312 & 18,563711 & 494,0 \\
\hline 20. & 49,332981 & 18,561918 & 499,7 \\
\hline
\end{tabular}

